\title{
A agenda internacional depois da Guerra Fria: novos temas e novas percepções
}

\section{EIITI SATO*}

Este trabalho visa analisar como e em que sentido as transformações ocorridas na estrutura das relações internacionais se refletem na agenda internacional. Ao longo do último quarto deste século, um fenômeno tão central como a Guerra Fria deixou de existir sem que estudiosos de qualquer tendência tivessem previsto sua ocorrência e, em seu rastro, uma variada gama de temas passaram a ocupar as atenções dos analistas e formuladores de política. Hoje, está bastante claro que esse fenômeno está relacionado com mudanças complexas e inter-relacionadas entre si na tecnologia, na estrutura da produção e do comércio, nos fluxos financeiros e nas relações de poder.

A agenda internacional caracteriza-se pela mudança contínua. Essa característica é uma decorrência da própria natureza do meio internacional, composto de atores em contínua transformação, e também altamente sensível a mudanças nos padrões econômicos e sociais. Mudanças tecnológicas, por exemplo, em um curto espaço de tempo, podem alterar fluxos comerciais e financeiros tornando um grande negócio de hoje uma atividade econômica inviável amanhã. Disponibilidade de mão de obra e de recursos naturais deixaram de ser, a médio prazo, garantias para as nações. Mesmo estruturas industriais maduras, para não serem ultrapassadas, precisam modernizar-se continuamente tanto do ponto de vista tecnológico quanto administrativo. Essas mudanças, obviamente, não ocorrem de maneira uniforme. Países e regiões não se transformam na mesma direção e quando, porventura, o sentido das mudanças pode ser considerado semelhante, a velocidade com que esse processo ocorre difere substancialmente de lugar para lugar. Além disso, fatores mais difíceis de serem percebidos e quantificados como os de base cultural e étnica podem combinar-se de muitas maneiras, em geral imprevisíveis, produzindo fatos e circunstâncias que condicionam a agenda internacional.

$\mathrm{Na}$ imprensa dos anos 60, a corrida armamentista entre a OTAN e o Pacto de Varsóvia ocupava lugar de destaque, ao lado de focos de tensão 
condicionados pela Guerra Fria nos vários continentes. Esse condicionamento também era visível no processo de descolonização onde, geralmente, os "movimentos de libertação” recebiam a ajuda soviética enquanto, por outro lado, apesar da luta pela independência ser travada contra as tradicionais potências coloniais européias, invariavelmente, as manifestações públicas favoráveis à descolonização incluíam a queima da bandeira dos Estados Unidos. Nessa época, questões desse tipo constituíam o que os analistas denominavam de "alta política" ou "grande política" (high politics), que definia o jogo de forças e as grandes estratégias de segurança internacional. As iniciativas e instâncias representadas por instituições como o GATT ou o FMI e as questões sociais eram classificadas como "baixa política" (low politics) indicando, claramente, que ocupavam posição secundária na agenda internacional.

Neste final de século, a agenda internacional se apresenta muito diferente. A separação entre high politics e low politics deixou de existir e novos itens passaram a ocupar lugar de destaque: meio ambiente, narcotráfico, as novas bases da competitividade internacional, direitos humanos, conflitos étnico-religiosos, entre outros. Na verdade, as questões relativas à segurança estratégica não deixaram de ocupar posição de destaque, mas passaram a ser vistas de modo cada vez mais integrado a esses novos temas da agenda internacional.

A maioria das análises produzidas nos anos 90 sobre as relações internacionais inicia destacando a importância central do fim da Guerra Fria como condicionante da política internacional. As razões são muitas, pois, sem dúvida, constituiu um evento central deste final de século e marcou mudanças importantes na maneira de se ver e conduzir a política internacional. No entanto, o fim da Guerra Fria não deve ser interpretado como um episódio e sim como parte de um amplo processo de mudança. Eventos como a queda do muro de Berlim e o colapso da União Soviética devem ser vistos por seu sentido emblemático, como um referencial importante, que deixa claro o fato de que o mundo passava a viver uma nova época.

Na condição de processo histórico, os eventos associados ao fim da Guerra Fria formaram, na verdade, o epílogo de uma longa sucessão de fatos. De um lado, porque, tanto a queda do muro de Berlim quanto o colapso da União Soviética, não teriam acontecido se as bases políticas e econômicas que davam sustentação ao bloco socialista não estivessem já deterioradas a ponto de tornarem inócuas quaisquer tentativas de reforma do sistema. Enquanto, por outro lado, também a disputa por áreas de influência pelos dois pólos de poder já vinha perdendo impulso desde a segunda metade dos anos 70 quando, não apenas a détente passou a marcar a política externa das grandes potências, mas também, visivelmente, muitos eventos de destaque no cenário internacional passaram a ter cada vez menos relação direta com a disputa bipolarizada, típica da Guerra Fria. Assim sendo, a análise das mudanças ocorridas no sistema internacional deve considerar vários 
desenvolvimentos que ocorreram ao longo de, pelo menos, duas décadas. Esses desenvolvimentos estavam associados a mudanças tecnológicas e econômicas e, até mesmo, a transformações no quadro de valores sociais, que faziam emergir um novo conjunto de referenciais para a política exterior dos países.

Apesar de tudo, a Guerra Fria foi, ao longo de quatro décadas, ao mesmo tempo, produto de uma época e também justificativa para a ação política. Estratégias de segurança, programas internacionais de cooperação técnica e econômica e até mesmo disputas políticas dentro dos países geralmente eram consideradas a partir do entendimento da Guerra Fria como um referencial importante, às vezes central, nos processos de tomada de decisão. Em conseqüência, o seu desaparecimento trouxe também, para os analistas, a tarefa de encontrar novas explicações para as possíveis forças que moveriam a política internacional.

\section{Mudanças nas percepções acerca do meio internacional}

O contexto ideológico, apesar de ser uma noção bastante fluida, não há nenhuma dúvida de que é muito real, sendo uma condicionante central para qualquer avaliação de estratégias de ação tanto no contexto interno quanto externo. O ambiente ideológico define a maneira pela qual a realidade é percebida servindo, por essa razão, de orientação para as ações. O homem primitivo olhava as nuvens no céu, sentia a brisa na pele e fazia conjecturas sobre a colheita; outras vezes consultava o oráculo que o aconselhava sobre a guerra, a paz e o futuro. Na modernidade, o avanço da razão e dos conhecimentos tem feito os homens tentarem compreender possíveis relações de causa e efeito ocultas sob fatos e números que mostram fenômenos como o tamanho das populações, o movimento das trocas comerciais, ou a eleição de governantes liberais, conservadores ou socialistas.

O século XIX, por exemplo, foi um período em que o liberalismo parecia oferecer as melhores respostas para as questões da riqueza, do emprego e da renda. Não foi acidental que ADAm SмIтH intitulou sua obra Uma Investigação sobre a Natureza e a Causa da Riqueza das Nações. A visão contida em sua obra, apesar das variadas interpretações e dos desdobramentos que se seguiram, em sua essência, predominou ao longo de todo o século XIX. A ordem econômica internacional, definida pela busca do livre comércio, pela liberdade na movimentação dos recursos financeiros e por um sistema monetário baseado na segurança da libra esterlina e na livre movimentação do ouro, refletia amplamente essa fé liberal. Aqueles que argumentavam em outra direção, como Alexander Hamilton, nos Estados Unidos, e Friedrich List, na Alemanha, que diziam que o livre comércio não era uma receita eficaz para todas as nações, permaneceram na penumbra. ${ }^{1} \mathrm{~A}$ idéia de que o comércio se constituía no "motor do crescimento" era uma percepção generalizada e tão 
indiscutível a ponto de Alfred Marshall, em seu Principles of Economics, escrever que “...crescimento econômico é uma questão afeita ao comércio internacional” sem ter que sustentar essa afirmação com argumentos de qualquer natureza.

Agora sabemos que as idéias de Hamilton e List, embora em desacordo com a visão predominante, estavam em sintonia com os esforços de industrialização de seus países. Por outro lado, é curioso observar que a Grã-Bretanha, a partir de 1919, vai liderar os esforços de retomada do padrão ouro, muito embora, nas condições da época, essa nação haveria de ser uma das mais prejudicadas com a volta desse sistema. Quer seja pelo fato de refletir a fé liberal, que renascia vigorosamente no pós-guerra imediato, ou pelo seu fato de ter se transformado em um símbolo da estabilidade internacional e da supremacia britânica, o fato é que a volta ao padrão ouro passou a ser defendido com entusiasmo apaixonado por estadistas e estudiosos.

No início dos anos 20, entre as raras vozes que discordavam do entusiasmo pelo padrão ouro, estava John MAYnARD KeYnes, um economista relativamente pouco conhecido à época. ${ }^{2}$ A grande maioria dos estadistas, conservadores ou liberais, e economistas das mais variadas tendências, entendiam que o padrão ouro trazia, implicitamente, a ordem e a disciplina necessárias à recuperação e à volta do crescimento da economia internacional.

No segundo pós-guerra deste século, o quadro das percepções havia se alterado de modo dramático. A dolorosa experiência da crise dos anos 30 havia mostrado as limitações da ordem liberal, que havia predominado no século XIX. Ao contrário do que havia ocorrido em 1919, na Conferência de Bretton Woods não se pensava em "reconstruir" a ordem econômica. Keynes e White tinham pontos de vista diferentes a respeito de como estruturar a nova ordem econômica internacional, mas ambos, assim como praticamente todos os demais participantes da Conferência, concordavam em que essa ordem deveria ser substancialmente diferente daquela que havia fracassado nos anos 30 . O comércio de commodities deveria ser administrado e as finanças internacionais deveriam ser manejadas pelas autoridades nacionais e agências internacionais que, dessa forma, evitariam as oscilações danosas dos preços nos mercados de commodities e a volatilidade dos capitais, que haviam estado no âmago do processo de desencadeamento da crise dos anos 30 .

Os primeiros anos do segundo pós-guerra presenciaram também a emergência de outro elemento condicionante das percepções que iriam influenciar fortemente as relações internacionais: a Guerra Fria. Os argumentos de Keynes, economicamente consistentes, a respeito da falta de liquidez internacional não foram aceitos em Bretton Woods, mas foram amplamente atendidos a partir de 1947, depois que as disputas e rivalidades da Guerra Fria foram transformadas em prioridades na agenda internacional por parte dos 
Estados Unidos. Com efeito, as expressivas somas transferidas para a Europa pelo Plano Marshall praticamente resolveram a carência de liquidez internacional, à sombra de uma doutrina de segurança estratégica internacional voltada para a contenção do avanço soviético.

Nesse contexto, a América Latina em geral, e o Brasil em particular, ficaram à margem das prioridades da política externa americana, significando também que ficaram à margem da única fonte de recursos financeiros para 0 desenvolvimento na época. Entre outras razões, essa circunstância decorria, paradoxalmente, do fato de não se constituírem em regiões problemáticas para os Estados Unidos no mapa das possíveis zonas de confrontação leste-oeste. Programas como a Aliança para o Progresso, com vistas à promoção do desenvolvimento econômico na região, somente passaram a ocupar posição de prioridade na agenda da política exterior dos Estados Unidos no início dos anos 60, depois dos violentos protestos contra o então Vice-Presidente NIXON em visita a algumas capitais da América do Sul e, mais particularmente, depois da ascensão de Fidel CAstro. Desde então, ficava claro que a América Latina poderia, perfeitamente, derivar para área de influência soviética. Assim sendo, passava a ser adequado aplicar, nessa região, fórmulas semelhantes àquelas que haviam produzido, com sucesso, a reconstrução econômica da Europa e assegurado a sua manutenção dentro da aliança estratégica ocidental.

O fim da Guerra Fria teve um papel importante na mudança da agenda internacional. A mudança não apareceu de modo tão evidente na composição dessa agenda, mas sim no grau de importância atribuída às diversas questões. Isto é, a maioria das questões integrantes dessa agenda já existia, no entanto, a maneira pela qual essas questões passaram a ser percebidas é que sofreu transformações significativas com o fim da Guerra Fria. Com efeito, a promoção dos direitos humanos constitui tema tradicional da ONU (a Declaração Universal dos Direitos Humanos foi adotada pela Assembléia Geral em 1948), o tema do meio ambiente já havia sido objeto de uma conferência mundial em 1972 (Estocolmo) e a globalização é um fenômeno cujas raízes se assentam no próprio conceito de modernidade. Até mesmo a "desregulação" dos mercados financeiros, considerada um verdadeiro símbolo da globalização, já ganhava impulso com a expansão dos mercados de eurodólares nos anos 60 e 70. O fim da Guerra Fria, no entanto, fez com que as preocupações e as abordagens de questões como essas deixassem de ser matizadas ou mesmo distorcidas pela disputa leste-oeste. Nesse sentido, uma organização de defesa dos direitos humanos não deveria mais ser encarada como parte de uma ação concertada para desestabilizar governos simpatizantes de um dos lados e a promoção das questões ambientais, comerciais e financeiras passavam a ser, nas mesas de negociação, objeto de novas alianças, deixando de lado 
considerações de segurança estratégica internacional típicas do jogo de poder da Guerra Fria.

\section{Segurança estratégica e relações econômicas na agenda internacional}

O abandono da dicotomia high politics e low politics foi um desenvolvimento importante, que reflete as novas percepções contidas na nova agenda internacional. A distinção entre as questões relativas à segurança estratégica e as questões econômicas e sociais, que caracterizava a agenda internacional, na realidade, não resultava de diferenças na natureza dos fenômenos dessas duas áreas. A interconexão entre recursos de poder militar e vitalidade econômica das nações sempre foi considerada muito importante pelos estudiosos. Eventuais discussões surgidas quanto à primazia de um campo em relação a outro, quando vistas sob uma ótica mais precisa, assumiram sempre o caráter do velho dilema "do ovo e da galinha".

Com efeito, a primazia atribuída à segurança internacional ou ao progresso econômico dependia das circunstâncias e da agenda internacional em pauta e também, obviamente, da posição ocupada pelo país no cenário internacional. Muitas iniciativas do Governo Americano, a começar pelo Plano Marshall, tiveram por premissa a necessidade de fomentar a recuperação e o crescimento econômico como base de sustentação de uma estratégia de segurança internacional. De modo semelhante, mas por razões diferentes, muitas das ações de política externa de países do então chamado Terceiro Mundo insistiam na inadequação do condicionamento do meio internacional ao conflito Leste-Oeste. No início dos anos 60, a chamada "Política Externa Independente” do Governo Brasileiro já refletia com notável clareza essa percepção.

A razão porque, até meados dos anos 70, essa distinção entre high politics e low politics tinha importância relevante derivava do quadro político internacional fortemente condicionado pelas percepções geradas pela Segunda Guerra Mundial e pela sucessão de crises associadas à Guerra Fria. A Segunda Guerra Mundial, além de suas dimensões trágicas, foi também percebida, por muito tempo, como um capítulo que apenas dava continuidade à tradição imemorial das nações, especialmente das grandes potências, de recorrer ao uso da força para resolver disputas por fronteiras, direitos de sucessão, domínios coloniais, rotas comerciais, etc. A novidade que surgia no século XX era a ampliação dessa noção de conflito para uma escala virtualmente global, à qual se somava o desenvolvimento da tecnologia das armas de destruição em massa. Nada de novo havia surgido que pudesse fazer supor que o relacionamento entre povos houvesse mudado em sua essência. Ao contrário, as duas guerras mundiais haviam apenas servido para mostrar que o meio internacional continuava essencialmente conflituoso e que, em razão da crescente interdependência entre os países, esse potencial havia se tornado 
ainda maior. Diferentemente do que ocorrera com a Primeira Guerra Mundial, a Segunda Guerra, apesar de suas dimensões muito mais trágicas, em momento algum foi entendida como "uma guerra para por fim a todas as guerras".

De fato, a frustração produzida pela Liga das Nações reforçava essas percepções acerca da natureza intrinsecamente conflitiva do meio internacional. No entreguerras, em torno da Liga das Nações, pensadores e estadistas construíram um imenso edifício de esperança e fé na razão, na democracia e em valores morais que, a partir de então, deveriam passar a alicerçar a sociedade mundial. No entanto, a crise econômica dos anos 30, a ascensão de regimes anti-democráticos e, por fim, o trágico balanço da Segunda Guerra Mundial produziram uma enorme reversão nessas percepções. Nesse ambiente, tornava-se difícil, tanto para governantes quanto para a opinião pública, acreditar que a política internacional, algum dia, poderia deixar de ser uma arena onde, mais cedo ou mais tarde, a política de poder não acaba, invariavelmente, resultando em conflito armado entre as nações.

Analistas do porte de Morgenthau ${ }^{3}$ traduziam as percepções dominantes do realismo político, caracteristicamente cético em relação a uma possível ordem internacional estavelmente sustentada sobre instituições e ordenamentos jurídicos supra-nacionais. Pode-se dizer que a famosa assertiva de Clausewitz de que "a guerra é a continuação da política por outros meios"4 era entendida não como uma forma possível de condução da política exterior das nações, mas como uma forma de ação política provável das nações face à insegurança predominante na política internacional.

Efetivamente, depois da Segunda Guerra Mundial, ao longo de um quarto de século, o cenário internacional foi marcado por tensões e conflitos sucessivos originados a partir de razões variadas, mas sempre apoiados pelas grandes potências, que viam nesses conflitos manifestações da disputa sem quartel por áreas de influência entre as duas ideologias, assentadas sobre duas alianças estratégicas antagônicas. Assim, a percepção era a de que, potencialmente, a qualquer momento, esses conflitos poderiam se degenerar, transformando-se em uma confrontação direta entre as grandes potências. Além disso, no plano doméstico, o fator ideológico servia para justificar regimes autoritários e medidas de exceção. Esse ambiente fazia com que muitas questões econômicas e disputas políticas triviais fossem transformadas em focos de tensão que transcendiam os limites locais e regionais. Todo o processo de descolonização, por exemplo, foi fortemente condicionado por esse fator ideológico. A Guerra Fria, desse modo, era percebida como o conjunto de motivos e justificativas peculiares ao mundo de meados do século XX, sobre os quais a velha política de poder entre as nações continuava a ser praticada.

Mudanças nessa percepção começaram a aparecer ainda nos anos 60 e, curiosamente, as armas nucleares, por seu potencial de destruição e pela impossibilidade de conter seus efeitos dentro de limites geográficos administráveis, acabaram por ajudar a questionar o uso da força como instrumento de solução de 
conflitos entre as grandes potências. A crise dos mísseis de Cuba, em fins de 1962, pusera em evidência essa questão, dando início às primeiras conversações entre as superpotências para tentar limitar o ímpeto da corrida armamentista.

Sob certos aspectos, as doutrinas estratégicas formuladas nesse contexto também refletiam essa atitude. Mesmo a doutrina da retaliação maciça (massive retaliation), cujo sentido era o de deter o rival por meio da posse de capacidade de destruição maciça, implicitamente significava criar desestímulos ao uso da força. Era uma espécie de versão extremada do antigo adágio si vis pacem, para bellum. Posteriormente, com o poderio nuclear estratégico das superpotências relativamente equilibrado, a doutrina que ficou conhecida como second strike deixava ainda mais clara essa idéia de conter possíveis iniciativas do adversário por meio da posse de superioridade estratégica: o receio dos efeitos destrutivos das armas atômicas conduzira à crença de que a única forma de evitar que o adversário tomasse a iniciativa do ataque e, assim, provocasse a sua aniquilação, seria dispor de recursos tecnológicos para revidar esse ataque, ainda que a nação atingida por armas atômicas já estivesse completamente destruída.

$\mathrm{O}$ fato é que as armas atômicas não foram empregadas, nem na guerra da Coréia, onde dezenas de milhares de soldados americanos foram mortos em uma época em que os Estados Unidos detinham enorme superioridade estratégica. A crise dos mísseis de Cuba, por sua vez, pode ser considerada um marco importante na mudança de percepções sobre as noções de segurança estratégica internacional. Ao colocar pela primeira vez, desde a criação da OTAN, as duas superpotências em uma situação de confrontação direta e ao se chegar a considerar publicamente a possibilidade do emprego de armas atômicas, serviu para pôr em evidência a insensatez da corrida armamentista na era nuclear.

Nesse quadro, a doutrina da coexistência pacífica do lado soviético vai ter, em seguida, sua correspondência na détente do lado americano e, assim, a busca de padrões de convivência entre os blocos rivais surge como solução natural. Essa nova percepção tomou forma definitiva com o fracasso americano no Vietnã onde, apesar da inequívoca superioridade estratégica, os Estados Unidos não conseguiram submeter uma nação pobre, situada em um lugar longínquo. Por outro lado, em geral, atribui-se importância central ao fracasso no Afeganistão para que a União Soviética também adotasse uma política mais tolerante de convivência com o Ocidente, mas os estudos mais recentes têm mostrado que, nos vinte anos que precederam a queda do muro de Berlim, os problemas econômicos já eram uma fonte de dificuldades crescentes para a sustentação de uma política de ações externas mais amplas e ousadas por parte da União Soviética.

Esses fatos, obviamente, não significam que os conflitos armados tivessem deixado a agenda da política internacional. Significam apenas que esses conflitos deixaram de ser percebidos como inexoravelmente ligados à confrontação entre as duas alianças estratégicas. A Guerra dos “Seis Dias”, o conflito Irã/Iraque e o 
fracasso soviético no Afeganistão foram apenas alguns entre os muitos conflitos armados que tiveram lugar depois da crise dos mísseis de Cuba. Evan LuARD lista duas dezenas de conflitos internacionais, que resultaram em ações militares em todos os continentes nos vinte anos que se seguiram à crise dos mísseis de Cuba. ${ }^{5}$ Esse número, sem dúvida alguma, seria muito maior se fossem incluídas as guerras civis. Mesmo agora, na última década deste século, o mundo vem assistindo a uma sucessão de guerras localizadas em diferentes partes do mundo, inclusive na Europa. O que, no entanto, claramente se tornava uma possibilidade cada vez mais remota, era uma confrontação direta entre as grandes potências, com o emprego de armas nucleares. Como esse fato tem sido interpretado e como seus possíveis desdobramentos têm sido entendidos têm assumido muitas direções, todas elas, no entanto, desenvolvidas dentro da perspectiva de um novo quadro das relações internacionais.

\section{Visões acerca do sistema internacional depois da Guerra Fria}

Em meados dos anos 80, a obra de Richard Rosecrance intitulada The Rise of the Trading State ${ }^{6}$ despertou grande interesse entre os estudiosos das relações internacionais. Seu argumento central consistia na idéia de que o mundo político-estratégico estaria cedendo lugar ao mundo do comércio, isto é, a satisfação das demandas essenciais das sociedades estava passando a depender, cada vez mais, da qualidade das relações econômicas internacionais mantidas pelas nações e cada vez menos da capacidade estratégico-militar. O mundo político-estratégico, assentado sobre as noções de segurança de base territorial, argumenta ROSECRANCE, estava, rapidamente, cedendo espaço para o mundo do comércio, que permite às sociedades obter, por via pacífica, todas as matérias-primas e bens de que necessitam para assegurar a satisfação de suas necessidades de bem-estar e de progresso. Nesse quadro, a satisfação das necessidades materiais das nações passava, portanto, a depender muito mais de bons portos e de uma economia bem administrada do que dos tradicionais recursos de poder militar.

A experiência de quatro décadas, após a Segunda Guerra Mundial, revelava dados que corroboravam fortemente essas percepções. Entre as nações consideradas bem sucedidas, havia uma lista crescente de países com escassos recursos naturais. Alemanha e Japão eram apenas os casos mais notáveis. Na Europa, a partir do núcleo constituído pelos seis países que originaram a Comunidade Econômica Européia - CEE, o dinamismo econômico não se verificava apenas no campo da indústria e das finanças, mas passava a se estender até mesmo para o campo da agricultura, atividade que, tradicionalmente, era entendida como típica de países com grandes extensões de terra. Além disso, em que pese a comprovação de acusações de forte protecionismo contido na Política Agrícola Comum feitas pelos Estados Unidos e pelos países em desenvolvimento contra os países da CEE, 
a médio e longo prazos, não seria possível sustentar essa política a menos que as economias dos países da CEE possuíssem dinamismo suficiente para arcar com seus custos. Esses custos poderiam ser transferidos para a economia desses países na forma de preços domésticos mais elevados ou de subsídios governamentais que, naturalmente, teriam de ser alimentados por impostos e taxas cobrados de outras atividades econômicas, onerando, de qualquer modo, a sociedade e seu sistema econômico.

O fato é que a Europa industrial passava a apresentar consideráveis superávits na agricultura e o que tornava o argumento de ROSECRANCE mais plausível era o fato de que, comparativamente, os grandes países do Terceiro Mundo conseguiam resultados muito modestos e, além disso, no âmbito dessa categoria de países, as economias que mais se destacavam em termos de progresso econômico eram justamente aqueles notavelmente pobres em recursos naturais: os chamados Tigres Asiáticos. Outro argumento era o fato de que Japão e Alemanha, totalmente dependentes das importações no que tange às suas enormes necessidades de petróleo, não sofreram abalos significativos, ao longo da crise energética dos anos 70, enquanto os grandes países do Terceiro Mundo, mesmo os exportadores de petróleo, se viram imersos em um longo período de estagnação econômica e de endividamento que se estende até nossos dias. A conclusão geral é a de que os fatores tradicionais de produção (terra e mão-de-obra) deixavam de ser considerados estratégicos para a realidade emergente.

Uma linha de explicação para essa redução da importância relativa dos tradicionais fatores de produção era oferecida por PETER Drucker que, também em meados da década de 80, escrevia um artigo na revista Foreign Affairs sobre as mudanças na economia mundial. ${ }^{7}$ Drucker argumentava que, entre os aspectos que caracterizavam essa nova economia destacavam-se alguns “desacoplamentos”, gerando conseqüências para o comércio, para as finanças e para a distribuição dos empregos no mundo. Entre esses desacoplamentos, três seriam especialmente relevantes para a explicação da perda de importância relativa dos fatores tipicamente de base territorial: a) a mão-de-obra deixara de ser fator determinante dos custos de produção; b) o aumento da produção industrial havia se “desacoplado” das necessidades de matérias primas; c) os fluxos financeiros e o mercado de divisas deixaram de estar atrelados ao comércio internacional. Essas mudanças seriam uma decorrência de mudanças tecnológicas que alteraram, em um curto espaço de tempo, os padrões de produção e de competitividade. Outra conseqüência inevitável foi o alargamento da distância entre os países industrializados e as economias do então chamado Terceiro Mundo, que se assentavam fortemente sobre as exportações de uns poucos bens primários e produtos manufaturados de baixo valor agregado.

Embora houvesse algum otimismo em relação à possibilidade de que os avanços tecnológicos não significassem redução nos níveis de emprego, dados 
históricos, muito anteriores à crise do sistema Bretton Woods, mostravam que, depois da crise dos anos 30, era possível observar a existência de um "resíduo tecnológico" que explicava pelo menos 1/3 dos aumentos da produção nos Estados Unidos, isto é, o aumento da força de trabalho e os investimentos de capital explicavam apenas $2 / 3$ e não a totalidade dos aumentos da produção. ${ }^{8}$ Com os avanços tecnológicos dos anos 70 e 80 essa tendência apenas tornou-se mais acentuada seja com o uso cada vez mais intensivo da automação, seja com a introdução de novas técnicas gerenciais, inicialmente pelo Japão e, depois, por todos os principais centros dinâmicos da economia internacional.

No que se refere ao "desacoplamento" entre a produção industrial e o consumo de matérias primas, um estudo publicado na revista Scientific American, em 1986, com o título de Beyond the Era of Materials, analisava, entre outros itens, o emprego do aço na economia americana mostrando que de 1880 a 1930 o consumo de aço crescera de $70 \mathrm{~kg}$ para $200 \mathrm{~kg}$ para cada US\$1.000 do PNB e que, no entanto, a partir de 1930 essa quantidade de aço consumida para cada US\$ 1.000 do produto passa a declinar até voltar, em 1980, aos mesmos níveis de cem anos atrás. ${ }^{9}$

A importância dos fluxos financeiros para o comércio sempre foi reconhecida. A visão tradicional da análise econômica, todavia, considerava o comércio como um estimulador desses fluxos a ponto de muitos economistas considerarem o comércio como "motor do crescimento". Em seu artigo, DRUCKER, no entanto, mostrava que as transferências de fundos entre os mercados financeiros do mundo ultrapassavam em dezenas de vezes o valor do comércio internacional. Esse fato significava que, em última instância, esses fluxos não dependiam do comércio, sendo mais plausível entender que, ao contrário, a movimentação de fundos passava a ter capacidade de influenciar os mercados de bens e serviços internacionais. Desse modo, os principais centros financeiros do mundo, e não os países territorialmente bem aquinhoados, cada vez mais, aumentavam seu poder de orientar os fluxos de comércio internacional.

Na verdade, desde os primórdios da modernidade, o argumento de que o comércio (e por extensão, o mundo das transações econômicas) poderia substituir a pilhagem e a conquista pela força vem recebendo a atenção de pensadores diversos. De acordo com a chamada tese do "suave comércio", isto é, do comércio como atividade moral que, no dizer de Montesquieu, pelo seu poder civilizador, suaviza os costumes tornando as pessoas e os povos menos belicosos. Essa tese foi incluída por Kant em seu Projeto de Paz Perpétua, escrito em 1795, como um dos pré-requisitos para que essa paz perpétua pudesse ser alcançada. Em conseqüência, o desenvolvimento do comércio, na formulação de KANT, desfruta de importância semelhante àquela atribuída à democracia, à consciência de cidadania universal e ao respeito a códigos de conduta na guerra em termos humanitários. 
No início dos anos 90, indubitavelmente, O Fim da História de Francis FuKUYAMA produziu enorme impacto sobre a reflexão política em todo o mundo. ${ }^{10}$ Suas observações partiam da constatação de que as chamadas sociedades póshistóricas (que o sociólogo DANIEL BELL chamava de pós-industrial) se caracterizam por compartilhar um conjunto comum de valores e aspirações baseados na democracia e na liberdade individual e, por essa razão, estariam fadadas a eliminar o uso da força militar como forma de resolver suas divergências. Conflitos continuariam a aparecer, mas estariam restritas ao âmbito de instâncias como o G7 e o GATT (na época em que escreveu o livro, a Organização Mundial do Comércio - OMC ainda não existia).

Além do título, extremamente provocante para a reflexão acadêmica, talvez o que mais tenha motivado respostas quase indignadas às suas formulações é a visão bastante pessimista a respeito do destino humano contida em seus argumentos. De acordo com FukuYAMA, a vida do “último homem” terá o tédio por característica. No mundo pós-histórico, o homem está fadado a ter uma vida sem privações e de relativa fartura, onde todos possuem mais do que o necessário para suas necessidades de sobrevivência, mas também será uma vida sem sonhos, sem ideais. Nas sociedades pós-históricas, os homens não estarão mais fazendo história, mas simplesmente se ocupando de cuidar dos museus, onde são guardadas as memórias da história construída e acabada. Ao lado desse mundo, sem privações, mas enfadonho, continuaria a existir um mundo histórico, mais numeroso, repleto de religiões e ideologias muitas vezes excludentes e violentas, e também cheio de privações, focos de doenças endêmicas e bolsões de pobreza. O mundo póshistórico, contudo, argumenta FUKUYAMA, de posse da maior parte da riqueza, da tecnologia e dos recursos de poder, perpetuará seu predomínio sobre o mundo histórico.

De certo modo, a indignação com que as teses do "fim da história” foram recebidas se assemelham ao que aconteceu com MALthus dois séculos atrás, quando seus contemporâneos (e, de certa forma, até hoje) passaram a vê-lo como um mensageiro de más notícias e, pior, entendendo que o cenário traçado, no fundo, refletiria, de alguma forma, o desejo do autor e não constituiria simplesmente uma interpretação de possíveis desdobramentos das forças econômicas e sociais em ação. De qualquer modo, independentemente de se aceitar ou não os argumentos de FuкuYAma, seu trabalho também pressupõe, implicitamente, a filosofia contida na tese do "suave comércio" de pensadores como Montesquieu e KanT, ou do "estado mercador" de Rosecrance.

Logo após a publicação do Fim da História, de Fukuyama, Samuel Huntington sugeria que seria um equívoco imaginar que as disputas entre unidades políticas possam ser limitadas ao campo do comércio e à busca do bem estar material em bases universais. Na visão de Huntington, especialmente depois do fim da Guerra Fria, com as ideologias que a sustentavam perdendo importância, as 
diferenças culturais entre os muitos povos do mundo teriam passado a ser centrais para a política internacional.

Com efeito, muitas dessas diferenças vêm assumindo feições tragicamente conflituosas, sendo o fundamentalismo islâmico apenas uma entre as muitas manifestações possíveis. Na visão de Huntington, fatores que permaneceram reprimidos ou camuflados por muito tempo, tais como heranças ancestrais, tradições, língua e religião, tendem a desempenhar papel cada vez mais decisivo para a redefinição das identidades nacionais e também para a formulação de objetivos e metas de política externa. Em unidades políticas multi-étnicas essa redefinição pode resultar em conflitos separatistas com grande potencial para se estenderem regionalmente, envolvendo outros países onde as etnias em choque se façam presente.

Em The Clash of Civilizations, esse autor argumenta que há no mundo sete ou oito grupos de culturas ou civilizações de maior expressão e que as grandes potências da atualidade pertencem a diferentes grupos. "A questão chave na agenda internacional, argumenta HunTington, envolve diferenças entre civilizações. O poder está se transferindo, depois de muito tempo, do Ocidente para as civilizações nãoocidentais. A política mundial tornou-se multipolar e multi-civilizacional”. ${ }^{11}$ Ao longo da história, sempre que ocorreu o fenômeno da transferência de poder, invariavelmente, o meio internacional se tornou mais instável, face ao inevitável surgimento de políticas revisionistas a respeito de fronteiras, direitos sobre regiões e fontes de recursos naturais, e outras demandas potencialmente geradoras de conflitos. Huntington argumenta que o meio mais eficaz de trazer mais estabilidade ao sistema internacional seria uma combinação de políticas não intervencionistas, por parte das potências, com um arranjo "inter-civilizacional” que congregasse as nações líderes daqueles sete ou oito grupos mais expressivos de culturas ou civilizações. Na sua avaliação, as instâncias internacionais, hoje existentes, foram concebidas dentro de uma outra época e não contemplam a multipolaridade e muito menos a variedade multi-civilizacional identificadas em The Clash of Civilizations.

Uma outra linha de interpretação a respeito dessas mudanças é aquela que entende que o sistema internacional não está mudando, mas está chegando ao seu fim. Segundo essa interpretação, o estado nacional, nascido a partir do colapso da ordem medieval, está em franca decadência e fadado a ser substituído por uma sociedade global. O sistema internacional que nos é familiar, em sua essência, é a projeção política de categorias tradicionais como estado, classe social e nação e, por essa razão, não é capaz de assimilar a dimensão planetária que os processos sociais vêm assumindo em praticamente todos os campos. Dessa maneira, a tradicional associação entre povo, território e governo soberano, no entendimento desses novos globalistas, perde continuamente seu significado na medida em que mercados se interligam de modo crescente, corporações industriais e financeiras 
têm seu raio de ação definido em termos de mercados globais, questões como meio ambiente e narcotráfico não podem ser tratados nos limites territoriais de um estado, e redes de comunicação interativa se estendem por todo o planeta. Nesse quadro, as fronteiras definidas pela geografia política tornam-se cada vez mais porosas, os governos nacionais perdem sua eficácia e novos atores têm se tornado cada vez mais importantes na definição do relacionamento entre povos e regiões. Essa nova realidade, de acordo com essa visão, precisa estar refletida nas instituições políticas.

Nessa linha de entendimento, desenvolve-se a idéia de que o tradicional sistema de Westphalia, constituído de estados nacionais soberanos, estaria sendo minado, rapidamente, por um processo de construção de instituições de governabilidade global. Em outras palavras, entidades nos vários campos das relações entre indivíduos e grupos vão assumindo a administração dos fluxos de comércio, das finanças, da disseminação de tecnologias, dos fluxos e processamento da informação, etc. Essa governabilidade incluiria também outras questões amplas e diversificadas como narcotráfico, proteção dos direitos humanos, direitos do consumidor e mesmo segurança internacional.

O argumento do fim do sistema de Westphalia começou a ganhar forma mais definida no princípio dos anos 90 e, entre os argumentos surgidos nessa época, destaca-se a idéia de que, face às mudanças em curso decorrentes de uma inusitada aceleração do avanço tecnológico, o estado estaria se tornando uma instituição disfuncional. Kenichi OHмAв, em artigo intitulado The Rise of the Regional State, publicado na revista Foreign Affairs (1993), argumentava que o estado havia se tornado demasiadamente grande para administrar questões de alocação de recursos produtivos e questões sociais, incluindo-se emprego, instrução, moradia, segurança pública, etc. Nessas questões as empresas e as comunidades locais seriam capazes de melhor entender e dimensionar as questões por estarem muito mais próximas dos problemas, sendo também estruturas muito mais leves e menos dispendiosas tanto nos processos decisórios quanto no manejo dos recursos necessários.

Por outro lado, continua o argumento, o estado tornou-se pequeno demais para administrar questões de natureza global ou regional. Meio ambiente, mercados internacionais de bens e serviços, fluxos financeiros, regimes monetários, desenvolvimento e transferência de tecnologia, sistemas de informação, etc., seriam casos que, tipicamente, só poderiam ser tratados por meio de organizações e instâncias que transcendessem os limites dos estados nacionais, que compõem a atual geografia política, e sobre os quais se assenta a concepção corrente de sistema internacional. OHMAE conclui que arranjos regionais poderiam ser uma resposta mais eficaz às demandas de novas formas de organização política.

Nessa perspectiva, a União Européia pode ser considerada um exemplo, em estágio mais avançado, de arranjo mais adequado ao tratamento de questões que, caracteristicamente, afetam toda uma região. Sua estrutura permite formular 
políticas mais adequadas para problemas ambientais, emprego, seguridade social, estabilidade monetária, e outras questões que, em geral, afetam regiões inteiras e não apenas países individualmente. Ao mesmo tempo, conclui o argumento, mecanismos baseados no princípio da subsidiaridade contidos na União Européia, permitem às comunidades tratarem questões locais ou limitadas a áreas específicas como transporte local, limpeza urbana ou segurança pública, de maneira mais apropriada e menos dispendiosa. Nesse arranjo a noção de soberania, tradicionalmente associada à figura do Estado Nacional, passa a ser institucionalmente diluída e o exercício da autoridade, por sua vez, se distribui por diferentes níveis ou instâncias, dependendo da questão em pauta.

A outra vertente de analistas que entendem que o sistema de Westfália estaria vivendo seu ocaso, desenvolve a idéia da construção de uma estrutura de governabilidade global e tem sua expressão mais elaborada na área do meio ambiente. Na verdade, de uma forma mais precisa, os formuladores dessa visão não argumentam que, necessariamente, o Estado tenha que desaparecer. Observam, no entanto, que, além de ter que dividir espaço com muitos outros atores, o Estado deverá sofrer revisões bastante drásticas em seus papéis e em suas instituições, sobretudo no que diz respeito às prerrogativas de soberania, tradicionalmente associadas à noção de Estado Nacional. Assim, indivíduos, instituições e organizações sociais se globalizam não apenas em decorrência da emergência de problemas com dimensões globais, mas também em razão do estreitamento das distâncias e dos mercados, pela permanente revolução nos meios de comunicação e transporte. Esse fato faz com que as instâncias políticas também sejam obrigadas a acompanhar esse processo.

Esses analistas entendem, portanto, que o Estado Nacional em sua concepção tradicional, que privilegia a noção de soberania, constitui um entrave ao estabelecimento de arranjos ou regimes que facilitem o tratamento de questões globais e permitam que as sociedades tenham condições de se beneficiar dos desenvolvimentos e dos conhecimentos produzidos de modo interativo em diferentes partes do mundo. Privilegiar a soberania, impedindo a integração de mercados, segundo essa visão, é condenar as empresas ao atraso, à ineficiência e, conseqüentemente, no longo prazo, à redução da própria produção e da renda.

Paralelamente, sob a denominação de regimes internacionais, desenvolveuse nos anos recentes várias formulações com vistas à abordagem de várias questões da atualidade. Notadamente no campo do meio ambiente, essa abordagem vem se configurando em torno de temas como mudança climática, regiões polares e aproveitamento de recursos naturais dos oceanos e do espaço cósmico. Oran YounG, destacado estudioso dessa ótica, em seu livro International Governance. Protecting the Environment in a Stateless Society (1994) procura reunir a base teórica e conceitual da abordagem dos regimes internacionais aplicados às questões ambientais. Sua formulação parte do pressuposto de que há uma distinção 
entre governo e sistemas de governança (ou governabilidade, segundo alguns autores). Sistemas de governança seriam as instituições e normas que orientam as ações e atitudes de indivíduos e grupos em relação a certas práticas sociais enquanto os governos seriam as organizações e os meios materiais que permitem o exercício da governança. A partir dessa distinção, Young argumenta que, sob certas condições, os governos podem se revelar não apenas ineficazes ou ineficientes para o sistema de governança, mas podem ser até mesmo desnecessários. Em seu lugar, arranjos transnacionais poderiam revelar-se muito mais eficazes.

A grande dificuldade dessa ordem de argumentos é a distribuição dos custos e responsabilidades. A implementação de arranjos transnacionais exigirá gastos e implicará também o emprego de instrumentos de coerção, isto é, em que medida iniciativas originárias de instâncias transnacionais que contrariem os interesses de atores de maior peso político serão efetivamente implementadas? Por outro lado, nações menos poderosas temem que essa forma de entender o meio internacional acabe servindo apenas para justificar ações intervencionistas das grandes potências.

Algumas iniciativas de alcance bastante amplo no sentido de estabelecer regimes internacionais para áreas típicas de interesse internacional têm sido levadas a efeito no campo das comunicações, da exploração espacial, do estabelecimento de bases na Antártida e, mais recentemente, na questão da mudança climática. Na verdade, nesses campos, os regimes internacionais têm sido formulados não a partir do pressuposto da "disfuncionalidade" do Estado, mas sim a partir da ação das soberanias ou na expectativa de que essas tradicionais soberanias sustentem sua implementação. Nas negociações do Protocolo de Kyoto, por exemplo, é interessante observar que a posição do Governo dos Estados Unidos a respeito das questões referentes à mudança do clima no planeta não coincidia com muitas das cláusulas incluídas no Protocolo. Os negociadores americanos, no entanto, acabaram por aceitá-las e, talvez mais importante, a implementação do regime estabelecido no Protocolo depende diretamente da disposição do Governo dos Estados Unidos e também dos Governos de outras importantes nações industrializadas que, assim, em última instância, acabam por se constituírem, nos verdadeiros garantes do Protocolo.

\section{O multilateralismo em um ambiente de opções variadas}

As várias visões acerca de possíveis lógicas que estariam movendo os fenômenos internacionais também têm sua correspondência no jogo de forças e no quadro institucional das relações internacionais. Por essa razão cabe discutir, ainda que de maneira breve, a questão do bilateralismo e multilateralismo na ordem internacional e a sua relação com as mudanças na distribuição do poder no quadro da política internacional nas últimas décadas. 
Do ponto de vista do jogo de forças dominante nas relações internacionais, fala-se que o mundo que emergiu da Segunda Guerra Mundial foi um mundo bipolar. Embora essa afirmação não seja incorreta, pode levar a uma idéia simplista, ou até mesmo equivocada, do significado dessa bipolaridade para as relações internacionais. A ordem bipolar deve ser entendida tanto na sua amplitude quanto na sua variação de intensidade ao longo do tempo. No pós-guerra imediato, apesar da criação da Organização das Nações Unidas, como entidade universal, de fato, houve também a formação de dois blocos antagônicos com percepções opostas sobre a segurança internacional, resultando na estruturação das duas alianças militares: a Organização do Tratado do Atlântico Norte e o Pacto de Varsóvia.

O surgimento dessas alianças rivais tornou-se, do ponto de vista da estruturação da ordem internacional, uma força francamente conflitante com o universalismo da ONU, criando enormes dificuldades para tornar mais eficazes os instrumentos de ação da entidade. Por exemplo, o emprego sistemático do direito de veto por parte dos membros permanentes praticamente paralisava as ações do Conselho de Segurança, uma instância essencial no processo decisório da organização. Entre 1946 e 1990, esse direito foi utilizado 279 vezes (124 vezes pela URSS, 82 pelos EUA, 33 pelo Reino Unido, 22 pela China e 18 vezes pela França). ${ }^{12}$ Em outras palavras, quanto mais fundamental e mais ameaçadora fosse uma crise ou foco de tensão em termos da estabilidade internacional, mais difícil era a obtenção do consenso no Conselho e, conseqüentemente, mais difícil valer-se da ONU como instrumento de solução de disputas internacionais.

Isso explica em grande parte porque a maioria das questões importantes de segurança internacional era conduzida à margem da ONU e o balanço de poder entre as forças da OTAN e do Pacto de Varsóvia tornava-se fator decisivo para a acomodação dos interesses que envolviam diretamente as grandes potências.

Outro aspecto, que também reforça a importância da influência de uma ordem bipolar ao longo do quarto de século que se seguiu ao fim da Segunda Guerra Mundial, é o fato de que iniciativas políticas dos EUA e da URSS tinham fundamento nessa visão da política internacional. Todo o processo de descolonização foi desenvolvido à sombra desse jogo de forças e a maioria dos envolvimentos das duas superpotências em conflitos localizados só podia ser explicada a partir desse quadro. Iniciativas levadas a efeito em regiões tão distantes como o TIAR (Tratado Interamericano de Assistência Recíproca), assinado no Brasil (Petrópolis, 1947) e a ajuda americana à Índia, em 1962, na guerra contra a China, pela posse de território fronteiriço na região do Himalaia, foram casos típicos que refletem a força da Guerra Fria como condicionante da ação política no contexto internacional no primeiro quarto de século que se seguiu ao fim da Segunda Guerra Mundial.

Entretanto, o mesmo quadro visto sob outro ângulo assume outra feição. No campo econômico, na prática, o mundo se apresentava unipolar. Uma vez feita a opção no sentido de pertencer a uma das alianças, as relações exteriores desses 
países estariam, automaticamente, condicionadas à política externa da potência hegemônica do bloco. No caso dos países do bloco soviético, não havia ilusões a respeito de possíveis opções de política comercial e financeira. O COMECON, mais do que um arranjo de cooperação econômica entre os países do bloco soviético, estabelecia os limites da ação econômica desses países. Na verdade, os planos econômicos elaborados em Moscou estipulavam metas e quotas de produção e consumo para todos os países do bloco.

No lado da aliança ocidental, o cenário da política internacional se apresentava mais difuso, com a possibilidade de alianças políticas e comerciais serem feitas dentro e fora da área de influência direta dos Estados Unidos. Esta era, contudo, apenas uma possibilidade e, por muitos anos, essa possibilidade revelara ser, na prática, muito remota em razão da enorme concentração da capacidade financeira e comercial na economia americana. Somente cerca de duas décadas depois do fim da guerra essa possibilidade de diversificação vai se tornar uma alternativa viável. Até meados dos anos 60 , a predominância da economia americana era evidente sob qualquer prisma.

Toda a ordem econômica internacional estruturada na esteira da Segunda Guerra Mundial foi baseada na posição hegemônica da economia americana: no campo monetário, o dólar passara a ser a moeda-chave do sistema; no campo financeiro, a economia americana era a maior credora internacional e a única a dispor de poupança suficiente para investir na reconstrução e desenvolvimento; no comércio, os Estados Unidos eram o único país em condições de prover a Europa e o mundo com bens essenciais, além de ser também o único com capacidade de realizar importações em níveis significativos para promover a recuperação econômica internacional.

Na Conferência de Bretton Woods, Keynes e outros negociadores reconheciam essa centralidade da economia americana. Na verdade, a proposta de KEYNES para a estruturação de um sistema monetário para substituir o padrão ouro previa a necessidade dos Estados Unidos proverem cerca de US\$ 25 bilhões para cobrir a falta de liquidez internacional. Depois de Bretton Woods, a reconstrução da economia européia vai ocorrer à sombra dos recursos proporcionados pelo Plano Marshall. A partir dos anos 50, os programas de desenvolvimento internacional vão ser fomentados, em termos bilaterais, diretamente pela agência de desenvolvimento dos Estados Unidos (USAID), ou multilateralmente, por meio do Banco Mundial, cujos recursos eram também, em sua maior parte, americanos. Iniciativas como a criação da UNCTAD (Conferência das Nações Unidas para o Comércio e Desenvolvimento), que não tinha a participação ativa dos Estados Unidos, apesar de ocorrer em 1964, permaneceu por muito tempo em posição bastante secundária. Assim, apesar do surgimento de inúmeras instâncias multilaterais, na prática, durante cerca de duas décadas os Estados Unidos se constituíram na fonte por excelência dos recursos para os programas de investimento no desenvolvimento internacional. 
Somente na década de 60, a recuperação da Europa e do Japão vai se completar, transformando-os em novos centros de dinamismo da economia mundial. A partir de então, o cenário internacional passa a exibir, gradativamente, um novo perfil do multilateralismo ou, mais precisamente, um multilateralismo de fato, pelo surgimento de alternativas reais à economia americana dentro de um quadro mais amplo de reorganização do sistema internacional. Se, de um lado, Europa e Japão davam início a um longo período de crescimento, ganhando espaço no comércio internacional e com suas moedas e suas finanças também ganhando espaço e credibilidade internacional, a economia americana, apesar do bom desempenho em termos de crescimento e apesar de viver um dos períodos de maior prestígio, começava a encontrar suas primeiras dificuldades.

Os Estados Unidos, em certa medida, passaram a viver uma situação semelhante àquela que a Inglaterra havia vivido nas três décadas que precederam a guerra de 1914-18, quando o seu prestígio internacional estava no zênite, mas, em termos relativos, a economia britânica revelava uma tendência secular declinante em seus padrões de competitividade internacional. Com efeito, no final da guerra, os Estados Unidos detinham quase três quartos das reservas de ouro do mundo e esse fato decorria da posição credora da economia americana, que havia sido favorecida por muitos fatores: a elevada produtividade, as vantagens de um grande mercado doméstico, a guerra que havia atingido de modo muito mais severo as economias européias, etc.

Em meados dos anos 50, os Estados Unidos eram, efetivamente, a única economia de massa do mundo. "A Europa e o Japão entraram, pois - à moda respectiva de cada um - na década de 20 dos norte-americanos...” escrevia W. W. Rostow em 1958, referindo-se ao fato de que, na década de 20, isto é, 30 anos antes, os Estados Unidos haviam vivido essa primeira onda de industrialização típica da sociedade de consumo de massa. ${ }^{13}$ Essa situação explica porque o dólar seria a moeda chave na ordem de Bretton Woods, mas, paradoxalmente, no momento em que Rostow expunha essas idéias, o nível das reservas de ouro dos Estados Unidos se reduziam, ultrapassando a barreira dos $50 \%$ das reservas mundiais e, no princípio da década de 60, esse fato passava a ser apontado pelos analistas como problemático para a estabilidade do sistema monetário internacional. ${ }^{14}$

Por outro lado, países como o Brasil, ainda no início dos anos 60, com a política externa independente, já manifestavam insatisfação com a agenda internacional onde predominavam as questões Leste-Oeste, típicas da Guerra Fria, insistindo, sem sucesso, na necessidade de que essa agenda fosse modificada, dando mais atenção ao desenvolvimento econômico dos países que passavam a ser identificados como Terceiro Mundo. A convocação da UNCTAD e a sua transformação em instância permanente tiveram motivação semelhante, isto é, 
refletiam a insatisfação dos países em desenvolvimento em relação aos padrões predominantes na política internacional.

A convocação da Rodada Kennedy, em 1963, tinha entre seus objetivos principais a revisão dos padrões de comércio entre os Estados Unidos e a Europa. Os déficits comerciais dos EUA, que no rastro do Plano Marshall eram vistos como parte importante da estratégia de recuperação da Europa, passavam a ser vistos cada vez mais como problemáticos para a economia americana e mundial. Assim, as transformações nas bases de sustentação da ordem econômica internacional continuavam a avançar rapidamente e apareciam na forma de crescentes dificuldades da economia americana até que, no início dos anos 70, os padrões de conversibilidade estabelecidos em Bretton Woods tornaram-se insustentáveis. Com efeito, o fim da conversibilidade do dólar em 1971, identificado como o fim do próprio sistema Bretton Woods, na verdade, era a expressão eloqüente desse processo de perda da posição relativa da economia americana no mundo.

\section{Responsabilidade e manejo da ordem internacional}

A estabilidade na ordem internacional é sempre transitória. O meio internacional está sempre em transformação mesmo quando existem forças capazes de serem caracterizadas como hegemônicas. Ainda nos anos 60, em face das condições difíceis de se implementar uma política externa para o Brasil no contexto da rivalidade leste-oeste, Araúso Castro falava de um "congelamento do poder mundial”, onde tanto Estados Unidos quanto União Soviética estariam igualmente interessados na manutenção do status quo internacional. ${ }^{15}$ Apesar de tudo, desde então, o sistema internacional passou por grandes e contínuas transformações, muitas delas impensáveis como, por exemplo, o próprio colapso da União Soviética. O recurso da análise teórica pode ajudar a compreender essa característica da ordem internacional.

Num congresso onde se discutia perspectivas para as ciências sociais, a professora de economia A. M. BIANCHI apresentou um trabalho muito sugestivo sobre as Ciências Econômicas intitulado Of clouds, clocks, and the hardest of the soft sciences. ${ }^{16}$ BIANCHI retoma o argumento de Popper de que existem, basicamente, sistemas de dois tipos: os sistemas que tendem a relógio e aqueles que tendem a nuvem. BIANCHI aplicava essa analogia ao caso da Economia, mas certamente poderia ser estendida às demais áreas do conhecimento.

As chamadas ciências humanas sempre sofreram de um complexo de inferioridade por não conseguirem, como as ciências físicas, desenvolver métodos e teorias que assegurassem a mesma precisão e previsibilidade dos fenômenos observados. A idéia de que os fenômenos, inclusive os físicos, podem ser distribuídos em um continuum que vai do sistema que se assemelha a um relógio de precisão 
até aquele semelhante a uma nuvem ou enxame de insetos, torna mais fácil aceitar as "imprecisões" das ciências sociais. Com efeito, o fato das nuvens serem fenômenos irregulares, desordenados e, em larga medida, imprevisíveis, não desqualifica o trabalho do meteorologista.

Do mesmo modo, as relações internacionais estão longe de serem fenômenos do tipo relógio havendo, no entanto, uma série de referenciais que ajudam na sua compreensão. Assim como a umidade do ar e a direção e a intensidade dos ventos constituem indicadores importantes e de grande objetividade para o meteorologista, para o analista das relações internacionais, fenômenos como a modificação nos fluxos de comércio, o aumento dos investimentos em defesa ou a emergência de movimentos nacionalistas também constituem referencias importantes e bastante objetivos para a avaliação do meio internacional.

É considerando esses referenciais de análise que dois aspectos merecem ser destacados para o entendimento do quadro das relações internacionais neste fim de século: o paradoxo do bem comum e o descompasso crescente no desenvolvimento das regiões. O paradoxo do bem comum, também conhecido como paradoxo de Olson, ${ }^{17}$ pode ser um pressuposto para se compreender as dificuldades de se estabelecer arranjos internacionais mais eficazes e o descompasso no desenvolvimento das regiões, como força impulsionadora de mudanças contínuas, ajuda a compreender o caráter eminentemente instável da ordem internacional.

\section{O paradoxo de Olson}

As questões da agenda internacional, em especial aquelas que se referem à promoção dos direitos humanos e aquelas que se referem à melhoria da qualidade de vida no planeta como um todo, estão sujeitas ao paradoxo de Olson. De maneira simplificada, esse paradoxo pode ser formulado da seguinte forma: quanto mais amplo e geral for o interesse de indivíduos e grupos sobre uma determinada questão, menos indivíduos e grupos estarão dispostos a participar efetivamente na sua implementação, destinando esforços e recursos para esse fim.

O argumento de Olson, estruturado a partir da análise de grupos sociais, notadamente sindicatos, baseia-se na idéia de que, quando há a percepção de que uma determinada questão interessa a um grande número de pessoas ou organizações, haverá sempre uma forte tendência à disseminação de um comportamento do tipo “carona” (free rider), à espera de que outras pessoas ou organizações realizem o esforço de implementar as medidas necessárias e, assim, ganhar os benefícios sem ter gasto tempo e recursos. A tendência à atitude de "carona” deverá ser tanto mais forte quanto maior for o universo de interessados e quanto menor for a possibilidade de que os ganhos não sejam particularizados. Isto é, um aumento de salário obtido por um sindicato é extensivo a todos os trabalhadores da categoria, não importando o nível de participação ativa de cada indivíduo dessa categoria na 
luta salarial. Esse fato, de acordo com Olson, explica a grande dificuldade das lideranças sindicais em conseguir adesões para iniciativas que incluam riscos e gastos como a organização de piquetes em porta de fábricas para assegurar a eficácia de um movimento grevista. Deixar de comparecer ao trabalho pode implicar custos como a perda do pagamento e, no caso dos ativistas, até a perda do emprego, além de ter de enfrentar possíveis ações repressivas da polícia. Entretanto, ao final, qualquer benefício auferido pelo movimento será estendido a todos os trabalhadores, mesmo àqueles que não tiveram nenhuma participação no movimento grevista.

Nessa linha de raciocínio, os bens públicos apresentam as características mais perfeitas para estarem sujeitas a esse paradoxo e, na agenda internacional, a estabilidade, os direitos humanos, a qualidade ambiental são, tipicamente, bens que devem interessar "igualmente" às nações. Por que um país relativamente pobre deve adquirir equipamentos e realizar investimentos por um "meio ambiente limpo" quando a sociedade é carente de muitas outras prioridades básicas? Em que medida cada país, individualmente, se beneficia da paz internacional? Por que um país, ainda que seja poderoso, deve assumir responsabilidades sobre programas internacionais de longo prazo sabendo que o futuro é incerto por natureza? Muitas questões como essas provavelmente são levantadas pelos governos, que dependem de votos de eleitores e do apoio de partidos políticos, normalmente muito mais sensíveis às demandas por emprego e por crescimento econômico do que pelos chamados temas globais.

Em grande medida, esses referenciais analíticos ajudam a explicar a atitude das nações, especialmente das grandes potências, que vêm dando prioridade aos seus interesses individuais mais imediatos e, sistematicamente, levantando a questão da distribuição dos custos das iniciativas e da manutenção das atividades das organizações multilaterais. Seja nas operações de paz, na formulação de medidas com vistas à proteção de refugiados ou na busca de arranjos e programas de proteção ambiental as nações tendem a não se sentir individualmente responsáveis. Os custos devem ser divididos e, além disso, considerando-se que as principais razões gravitam em torno de considerações morais, uma política de envolvimento com essas questões encontra dificuldades em competir com outras prioridades dentro do processo decisório das nações.

Mesmo nos casos em que as ameaças podem estar geograficamente próximas, como os Bálcãs, as grandes potências européias têm se mostrado mais preocupadas em simplesmente evitar que os efeitos dos conflitos na região se estendam para dentro de suas fronteiras, especialmente na forma de correntes migratórias de refugiados. A busca de soluções capazes de trazer uma estabilidade mais duradoura para a região é politicamente mais complicada e financeiramente mais dispendiosa e assim, dificilmente, os governos se sentem em condições de arcar com esses custos, preferindo apoiar a "comunidade internacional” nesse 
esforço.

Nesse quadro, as mudanças no cenário internacional para um padrão mais multipolarizado também trazem, inevitavelmente, mais dificuldade para o estabelecimento de responsabilidades no manejo da ordem internacional. A bipolaridade da Guerra Fria, como já mencionado, sugeria estratégias de segurança e desenvolvimento internacional facilmente inteligíveis às bases eleitorais e partidárias das lideranças políticas e, geralmente, seus argumentos se sobrepunham sem muita dificuldade às demais demandas sociais. A multipolarização tende a diluir essas noções e traz mais dificuldade na distribuição de responsabilidades entre as sociedades mais poderosas.

Na Guerra do Golfo, logo após o colapso da União Soviética, em termos militares, os recursos proporcionados pelos Estados Unidos foram incomparavelmente maiores do que os de seus aliados, no entanto, países como o Japão e a Alemanha pagaram considerável parte desses custos. ${ }^{18} \mathrm{O}$ descompasso entre o enorme interesse do Japão na contenção da política expansionista de Saddan Hussein e na estabilização da região e os seus limitados recursos de poder militar seriam a justificativa para esse check book diplomacy. Esse fato, todavia, levanta também a questão do futuro das políticas de segurança: em que medida e até que ponto o Japão estará disposto a ter sua segurança externa dependente diretamente da política de segurança dos Estados Unidos? A questão pode ser posta de outra maneira: até que ponto os interesses de segurança externa do Japão e dos Estados Unidos serão convergentes?

De uma forma mais geral, o novo quadro das relações internacionais, em grande medida, se apresenta sujeito à lógica do paradoxo de Olson. Por que os fundos, que são arduamente disputados na distribuição dos recursos do orçamento público, devem ser destinados à manutenção de organizações e forças internacionais de paz? Por que as questões de segurança internacionais não são tratadas simplesmente a partir das considerações de segurança doméstica? No plano da ordem econômica internacional, por que empregos domésticos devem ser sacrificados em favor de medidas com vistas à estabilidade e ao crescimento econômico internacional? Como explicar aos deputados e aos eleitores que os recursos destinados a programas de ajuda econômica internacional se transformam em benefícios para a economia do país?

\section{Os desequilíbrios internacionais}

Quanto ao aumento do desequilíbrio entre as nações, como já foi mencionado, esse fenômeno reflete uma característica intrínseca do meio internacional: os países e regiões não vivem processos de mudança de modo homogêneo. Entre os países, o dinamismo tecnológico varia de setor para setor e, estruturalmente, também há a formação de focos de competência técnica e de 
resistência a mudanças. Por essa razão, do mesmo modo que, ao longo do primeiro século da revolução industrial, o mundo viu a emergência da Europa industrial, enquanto regiões onde floresceram antigas e pujantes civilizações declinavam em termos relativos, nas últimas décadas deste século, os centros industrializados avançam rapidamente em termos de progresso econômico, enquanto boa parte do antigo Terceiro Mundo se vê diante da estagnação e mesmo, em alguns casos, de verdadeiro retrocesso. Vários países da África sub-saariana, principalmente em razão de guerras civis, vivem o que alguns analistas chamam de déconnexion par défault ${ }^{19}$, enquanto outros, como os países da América Latina, embora relativamente mais estáveis e melhor estruturados em termos sociais e políticos, participam apenas marginalmente do dinamismo tecnológico e econômico deste fim de milênio.

Quando a noção de desenvolvimento econômico passou a ocupar destacada posição na agenda internacional, os índices de analfabetismo eram um dos indicadores mais importantes na definição dos padrões de desenvolvimento econômico e social. Neste fim de século, informatização, integração a redes de comunicação e uso intensivo de tecnologia nas atividades mais tradicionais como a agro-pecuária tornam a alfabetização apenas um indicador social básico, que está longe de significar a existência de condições capazes de permitir à sociedade integrar-se efetivamente na vida econômica e social do mundo moderno. Pode-se afirmar, em uma analogia talvez um pouco exagerada, que as sociedades mais avançadas integram um mundo que já ultrapassou as revoluções da relatividade, da física quântica e da microeletrônica, enquanto as sociedades periféricas ainda tentam penetrar o universo "newtoniano". Enfim, sob muitas formas, o salto tecnológico do último quarto de século aumentou consideravelmente a distância entre essas categorias de sociedade.

Essa realidade, além das conseqüências imediatas em termos humanitários, dramáticas em alguns casos, apresenta outras facetas importantes para a ordem internacional que devem ser consideradas. A mais óbvia delas se traduz no fato de que, no longo prazo, a ampliação desse fosso traz consigo grande potencial de problemas uma vez que, quanto mais aumenta essa diferença, mais difícil se torna a integração dessas regiões na ordem política, econômica e social sob a liderança dos centros mais industrializados da América, Ásia e Europa. Esse processo pode produzir grandes focos de pressão sobre a ordem internacional, atingindo primeiramente as regiões mais próximas das sociedades retardatárias e, depois, se estendendo para o meio internacional como um todo. Essas pressões podem assumir formas corrosivas da ordem social como imigração desordenada, tráfico de armas e de drogas ilegais e crime organizado.

No longo prazo, esse processo pode contaminar instituições centrais para as relações sociais e a própria democracia. São cada vez mais freqüentes as denúncias de que a "lavagem de dinheiro" vai deixando de se restringir aos chamados 
paraísos fiscais para envolverem até instituições financeiras situadas em tradicionais centros industrializados. Nesse sentido, para os Estados Unidos, por exemplo, estabilidade e progresso econômico no México e Caribe podem ter efeito bastante positivo sobre sua própria sociedade. Em países como o Brasil, as preocupações com a ação dos grupos organizados em torno de atividades ilegais são crescentes. A região do Prata deixou de ser uma área de preocupação com eventuais questionamentos sobre limites territoriais para tornar-se um foco de preocupações com o contrabando, o narcotráfico e outros ilícitos que não apenas desconhecem fronteiras da geografia política, mas até mesmo valem-se dela como forma de fugir à ação do fisco e da polícia.

Esse desequilíbrio também deve ser visto como um potencial de oportunidade de crescimento e estabilidade para a economia internacional. Países como o Brasil têm muitos de seus problemas sociais claramente relacionados com seus próprios desequilíbrios sócio-econômicos, muito mais do que com o de seus países vizinhos. A melhoria desse quadro, no entanto, pode ter influência significativamente positiva sobre o crescimento econômico regional com efeitos consideráveis sobre a economia internacional como um todo: a inclusão de milhões de novos consumidores com certeza significaria uma substancial ampliação de mercados para bens, serviços e investimentos. Nessa perspectiva, a recuperação do dinamismo tecnológico constitui elemento fundamental para que essa integração internacional mais ampla possa ocorrer.

Obviamente, a recuperação desse dinamismo depende essencialmente das iniciativas individuais das sociedades, entretanto, dificuldades existentes em termos de comércio, de acesso a recursos financeiros, além da própria disseminação de tecnologias, poderiam ser reduzidas, facilitando, assim, a redução do fosso tecnológico que separa as nações mais industrializadas das sociedades menos desenvolvidas.

Muito embora a percepção dominante seja a de que a vitalidade da economia internacional depende apenas do vigor das chamadas economias centrais, cabe recuperar algumas lições da história. Com efeito, mesmo reconhecendo o papel periférico que certos países desempenham no contexto da economia mundial, a história mostra que, acompanhando a alternância dos períodos de crescimento e de crise, as chamadas economias periféricas têm sido percebidas de modos diferentes. Em períodos de crescimento, essas economias têm sido vistas com certo desprezo enquanto, por outro lado, ao final de longos períodos de crescimento, os chamados países periféricos têm sido vistos com atenção, como a chave para a continuação do processo de expansão econômica. Ocorreu no final do período que marcou o padrão ouro anterior a 1914 e ocorreu novamente nos anos 70 quando a crise energética pôs fim aos "anos dourados" das quase três décadas que se seguiram ao fim da Segunda Guerra Mundial. 
Neste fim de século, apesar do otimismo corrente quanto a uma possível manutenção de taxas de crescimento nas principais economias do mundo, há muitos sinais de que há focos de fragilidade e vulnerabilidade nos padrões de funcionamento da economia internacional. As elevadas taxas de desemprego continuam difíceis de serem contidas e empresas tradicionais encontram dificuldade para se sustentarem no mercado. No entanto, as regiões até há pouco identificadas como Terceiro Mundo, somente poderão ter algum papel significativo como elementos de estabilização se estiverem em condições de se integrarem mais efetivamente à economia mundial. O potencial de investimento em atividade econômica de baixa tecnologia está, em alguns casos, praticamente esgotado, ou é virtualmente irrelevante em face das grandes transformações tecnológicas das últimas décadas. No comércio mundial, por exemplo, as commodities hoje representam apenas uma pequena parcela do total. Nas bolsas de valores, não são mais as grandes corporações que possuem ativos em outros países na forma de plantações e companhias de comércio de commodities aquelas que têm as ações mais valorizadas, como ocorria até meados deste século, mas sim as companhias de alta tecnologia.

Os investimentos nas áreas de grande conteúdo tecnológico, contudo, são problemáticas para a maioria dos países em desenvolvimento. Esses investimentos implicam formas diversas de transferência de tecnologia e transferências de tecnologia somente são possíveis nos casos em que haja capacidade técnica instalada capaz de compreender e processar tecnologias com níveis semelhantes de complexidade, isto é, mão-de-obra adequadamente qualificada, base industrial em condições de fornecer peças e componentes, mercado relativamente bem estruturado, entre outras condições. Pode-se dizer que o nível de qualificação técnica necessária a uma sociedade para receber tecnologia não difere muito do nível exigido para promover a inovação tecnológica. Esse é, sem dúvida, um dos motivos que explicam porque mais de $80 \%$ do comércio mundial de patentes ocorre entre os países industrializados.

O atraso tecnológico, portanto, resulta na exclusão dos fluxos internacionais de investimento o que leva também, inexoravelmente, à impossibilidade de que países com estruturas tecnológicas precárias se constituam em fatores efetivos de estabilidade e crescimento da economia internacional.

\section{O Estado e a estratégia de inserção internacional}

À guisa de conclusão, cabe uma consideração sobre as perspectivas para os problemas aqui tratados. Neste fim de século, a complexa agenda internacional não se diferencia muito daquela que predominava na última década da Guerra Fria em termos de sua composição. Na verdade, a maioria das questões hoje consideradas de destacada importância já integrava essa agenda, 
como são os casos da proteção dos direitos humanos e do meio ambiente. Há, no entanto, na atual agenda internacional, diferenças substanciais quanto à forma como essas questões são percebidas e encaminhadas. Uma componente importante dessas percepções em mudança refere-se aos papéis atribuídos aos atores envolvidos. Há consenso a respeito do papel cada vez mais ativo de atores não estatais (notadamente as organizações não-governamentais ONGs e as empresas transnacionais) e há também uma crescente sensibilização acerca da necessidade de que novas instâncias transnacionais sejam criadas ou antigas instituições sejam redirecionadas a fim de tratarem, de modo mais eficaz, questões que afligem vários países ou mesmo a totalidade do planeta. Há até mesmo alguns que entendem que o mundo está entrando em uma fase em que a própria noção de "relações internacionais" deveria ser substituída pela idéia de "governabilidade global”. Assim sendo, a título de conclusão, parece oportuno tratar do papel dos principais atores no quadro das relações internacionais deste fim de século.

Como já discutido anteriormente, sob a temática da globalização, argumentos têm sido construídos sobre o fim do sistema de Westphalia e sobre o Estado como instituição anacrônica. Neste momento, obviamente não cabe retomar essa discussão, mas torna-se necessário apontar para algumas considerações importantes sobre o papel dos atores no encaminhamento de alternativas que se apresentam na agenda internacional.

Durante longo tempo, o Estado foi considerado como uma espécie de cornucópia de onde deveria fluir, inesgotavelmente, soluções para os problemas que afligiam as nações e as sociedades. No último quarto deste século, contudo, essa noção foi sendo substituída por um sentimento de ceticismo crescente. Esse sentimento vai se refletir na ideologia popularizada como "neoliberal", que não apenas retoma a fé na iniciativa privada e no mercado como instrumento de alocação de recursos, mas passa a encarar o Estado como fonte de ineficiência e desperdício.

O Estado continua, entretanto, sendo um ator central na ordem internacional por muitas razões, entre elas o fato de que o Estado continua sendo a garantia da ordem tanto no plano interno quanto no meio internacional. Mancur Olson, no livro que terminou de escrever pouco antes de sua morte, analisa o intrigante fenômeno da riqueza e pobreza das nações. ${ }^{20}$ Por que algumas nações se tornam ricas enquanto outras fracassam e, nos casos mais recentes, por que o fim do comunismo na União Soviética e em outros países da cortina de ferro não trouxe prosperidade, mas, ao contrário, muitas dessas nações estão em condições ainda piores? O argumento de OLson é que o Estado, enquanto elemento organizador da sociedade, tem um papel central na geração de riqueza. De sua eficácia depende o funcionamento das empresas e a ação dos demais agentes econômicos. Em países em que o Estado funciona 
mal, ou está em crise profunda em decorrência de guerras civis ou de corrupção disseminada por suas instituições, os agentes econômicos não encontram ambiente para desenvolver suas atividades, os investimentos não fluem para esses países e a escassa poupança nacional tende a migrar para outras sociedades mais organizadas. Apesar de tudo, há algumas dificuldades importantes a serem apontadas relacionadas à capacidade do Estado administrar as forças econômicas e sociais em ação.

Uma primeira ordem de dificuldades refere-se ao estreitamento dos limites da capacidade de formulação de políticas econômicas em decorrência da considerável redução ocorrida na eficácia da atividade de planejamento na administração da economia. As transformações ocorridas, especialmente nas duas últimas décadas, que alteraram substancialmente a velocidade das mudanças tecnológicas e os padrões de competitividade, produziram uma nova economia política. Nessa nova economia política são evidentes as inadequações de regimes autoritários caracterizados por governos que se auto-denominam porta-vozes da vontade do povo e se julgam capazes de definir objetivos e noções a respeito de "interesses estratégicos" da nação, sem uma interação ampla, dinâmica e aberta com as múltiplas forças em ação na sociedade.

Em outras palavras, as relações entre estado e mercado, no momento, estão passando por profundas revisões. O planejamento econômico perdeu bastante de sua eficácia enquanto os aspectos políticos das questões econômicas têm se tornado centrais no processo de tomada de decisão. Por outro lado, o aumento da incerteza e da sensação de que o potencial de instabilidade da economia internacional cresceu têm levado os governos a pensar com ansiedade em meios de controle. O uso da autoridade do Estado no plano doméstico e no plano internacional tem sido freqüentemente invocado como instrumento para reduzir os efeitos danosos de fenômenos como o da volatilidade dos fluxos financeiros. Todavia, até agora, as iniciativas em curso ainda estão muito longe de serem consideradas suficientemente eficazes e tranqüilizadoras. Além disso, até mesmo no que se refere às tradicionais funções do Estado, essa fragilidade também se evidencia para muitos países quando se considera as dificuldades de uma ordem democrática pouco consolidada, típica da maioria dos países em desenvolvimento.

A sociedade aberta e o regime democrático têm se revelado muito mais coerentes com as características do dinamismo econômico e social deste fim de milênio, mas requer considerável grau de amadurecimento das instituições para que se evitem quebras de continuidade e viabilizem programas de investimentos de longo prazo. Nesse contexto, a vulnerabilidade das economias em desenvolvimento às incertezas de um mercado em constante mutação aparece em toda a sua extensão na forma de sucessivas crises. Outros aspectos igualmente importantes a serem considerados são as incertezas que 
cercam os possíveis desdobramentos de processos de mudança política em curso em países onde o desenvolvimento e a modernização econômica convivem com regimes políticos autoritários. Qual a probabilidade de que processos de liberalização como o da China não resultarão em turbulência política, ao invés de desenvolvimento e integração à economia internacional?

Conforme mencionado, a realidade que emergiu do colapso do bloco soviético ficou muito longe das expectativas que cercavam a abertura da economia dos países que o compunham. De acordo com Olson, ao se levantar a cortina de ferro, ao invés de se ver surgir um vigoroso capitalismo nascente, surgiu a "máfia russa" e um enxame de quiosques da economia informal que se espalharam rapidamente pelas praças e outros logradouros públicos. Por outro lado, economias em desenvolvimento, que avançaram rapidamente na industrialização sob regimes autoritários, também encontram dificuldade no sentido de manter níveis elevados de eficiência econômica e, ao mesmo tempo, processar a democratização das instituições políticas. ${ }^{21}$

Essa realidade põe em evidência a importância de que estratégias de desenvolvimento econômico estejam associadas a iniciativas e medidas que assegurem a consolidação da ordem democrática. No estágio atual de integração das economias e de mudanças tecnológicas rápidas, o planejamento econômico torna-se um instrumento de limitada utilidade. Cabem, no entanto, às agências governamentais, novas funções essenciais com vistas à adequação das sociedades a esse quadro. Em suma, normas ou padrões de relacionamento entre estado e mercado devem ser revistos. A privatização constitui apenas uma dessas formas e, além disso, não são aplicáveis a todos os casos e, tão importante quanto a privatização em si mesma é a maneira de fazê-la. A desregulamentação, por sua vez, é também um processo complicado, especialmente para países como o Brasil, de grandes desequilíbrios regionais e de sistema federativo, uma vez que o impacto da desregulamentação incide de modo diferente sobre as regiões.

O nível de institucionalização das relações internacionais tem aumentado consideravelmente, evidenciando a necessidade de novos papéis e novas capacitações, entre elas a de participar ativamente de foros de negociação. Arranjos formais e regimes que procuram organizar a cooperação internacional têm surgido nos mais diferentes setores da atividade econômica e política das sociedades modernas. A Rodada Uruguai, por exemplo, foi marcada por duas características emergentes nas relações internacionais. De um lado, a ampliação da agenda de negociação traduziu-se na inclusão dos chamados "novos temas", que associou o comércio às finanças, à propriedade intelectual e às questões ambientais e sociais. De outro lado, o aumento do nível de institucionalização traduziu-se na transformação do GATT em Organização Mundial do Comércio. Além disso, os temas globais, que não 
podem ser abordados individualmente pelos países, têm se revelado cada vez mais críticos para as sociedades e também têm incluído um número crescente de países criando novas instâncias multilaterais. Meio ambiente, clima, narcotráfico e telecomunicações são apenas alguns entre os vários temas cujo tratamento não pode ser dissociado de sua dimensão internacional. Desenvolvimentos como esses mostram a importância do Estado dispor de instrumentos de negociação, de defesa de direitos e de meios para participar ativamente na construção de regimes internacionais nos mais diferentes domínios.

Na atualidade, diferentemente do que ocorria até duas ou três décadas atrás, é muito difícil de se construir um paradigma claramente definido para se caracterizar a realidade internacional. Até bem recentemente era possível reconhecer a existência de padrões e forças predominantes no meio internacional, notadamente a confrontação leste-oeste. Na atualidade, padrões como "globalização" e "emergência de atores não-estatais" são difusos por natureza, o que dificulta a formulação de políticas organicamente estruturadas. Além disso, do ponto de vista do Brasil, a considerável complexidade alcançada não apenas pela economia, mas pelo próprio perfil sócio-político do País como um todo, torna inviável a busca de objetivos e metas que satisfaçam, simultaneamente, os diferentes segmentos da sociedade. Os interesses econômicos, políticos e culturais, tanto em relação aos parceiros tradicionais quanto em relação a novos e potenciais parceiros, caracterizam-se pela multiplicidade ao mesmo tempo em que, internamente, os interesses são muito variados. As disputas recentes, genericamente designadas como "guerra fiscal”, são apenas manifestações de uma parte dessa diversidade. Essa realidade, muito mais variada e dinâmica, representa uma considerável ampliação de oportunidades, mas significa também maior dificuldade na construção de estratégias de inserção internacional.

Maio de 2000

\section{Notas}

${ }^{1}$ A. Hamilton, Report on the Subject of Manufactures, 1791. F. List, The National System of Political Economy, 1841. Um dos argumentos contidos nessas obras era a idéia de que o livre comércio pode ser benéfico para as economias situadas nas duas extremidades: as industrializados e as de base primária.

2 Ver J. M. Keynes, The Economic Consequences of Peace (1919) e também The Economic Consequences of Mr. Churchill (1925)

${ }^{3}$ Hans Morgenthau, “Politics among Nations”. Knopf, New York, 1948. “In Defense of the National Interest”. Knopf, New York, 1951. 
${ }^{4}$ Carl von Clausewitz, “Da Guerra” (1832). Editora Universidade de Brasília, 1979.

${ }^{5}$ E. LuArd, Conflict and Peace in the Modern International System. A Study of the Principles of International Order. Macmillan Press, London, (1968) 1988.

${ }^{6} \mathrm{R}$. Rosecrance, The Rise of the Trading State: Commerce and Conquest in the Modern World. Basic Books, New York, 1986.

${ }^{7}$ Peter F. Drucker, Sérias Mudanças na Economia Mundial. Revista Diálogo (USIS), n.o 2, vol. 20, 1987. Traduzido de Foreign Affairs, Spring, 1986.

${ }^{8}$ Denison, E. United States Economic Growth. Journal of Business, vol. 35, April, 1962, pp.109121.

${ }^{9}$ E. D. LARson et. al. Beyond the Era of Materials. In Scientific American, June, 1986, vol. 254, no. 6

10 F. FukuYama, The End of History and the Last Man. Hamish Hamilton. London, 1992.

11 S. P. Huntington, The Clash of Civilizations and the Remaking of World Order. Simon \& Schuster , New York, 1996 (p. 29)

12 E. S. FuנITA. O Brasil e o Conselho de Segurança. Notas sobre uma Década de Transição: 19851995. Revista Parcerias Estratégicas, Dez./1996, pp. 95-110.

${ }^{13}$ W. W. Rostow, Etapas do Desenvolvimento Econômico, (1958) Zahar Edit., R. de Janeiro, 1978, $6^{a}$ edição, p. 110.

${ }^{14}$ Robert TRIFFIN argumentava que a maneira pela qual o sistema monetário surgido dos acordos de Bretton Woods poderia ser mantido seria a transferência para o Fundo Monetário Internacional dos saldos obtidos pelos países em seu comércio com os Estados Unidos (R. TrifFin, The Gold and the Dollar Crisis. The Future of Convertibility. Yale University Press, 1960).

15 Amado, Rodrigo (Org.), Araújo Castro. Editora Universidade de Brasília, 1982.

${ }^{16}$ Bianchi, A . M. Of Clouds, Clocks, and the Hardest of the Soft Sciences. Trabalho apresentado no Annual Meeting of the Allied Social Sciences Association, Anaheim, CA, 1993.

17 Olson, Mancur, The Logic of Collective Action. Public Goods and the Theory of Groups. Harvard University Press, 1965.

${ }^{18}$ Nessa guerra os Estados Unidos teriam deslocado cerca de meio milhão de homens, isto é, cerca de cinco vezes mais que todos os demais aliados somados. Além disso, provavelmente muito mais decisivo, a disparidade dos recursos técnicos (aviões, mísseis, etc.) foram ainda maiores. (W. C. Mc Williams \& H. Piotrowski, The World Since 1945. A History of International Relations. Lynne Rienner Pub. 1997)

${ }^{19}$ Países como Somália, Burundi e Etiópia simplesmente se vêem abandonadas à própria sorte, não despertando o interesse das agências de fomento ao desenvolvimento e nem mesmo de mercadores gananciosos. Um dos casos mais dramáticos é o de Angola que, ao longo de um quarto de século vem sofrendo as conseqüências nefastas de uma guerra civil longa e sangrenta. Ver D. C. BACH, Avant-propos. Afrique: la Déconnexion par Défault. Edição especial de Études Internationales. pp. 245-251.

${ }^{20}$ M. Olson, Power and Prosperity. Outgrowing Communist and Capitalist Dictatorships. Basic Books, New York 2000.

21 Idem.

\section{Resumo}

A idéia central do artigo é que o fim da Guerra Fria no final da década de 1980 não deve ser interpretado como um episódio e sim como parte de um amplo processo de mudança. A partir desta idéia, tenta-se demonstrar, por meio de visões 
expressas em várias obras e artigos, que o processo que levaria ao fim da Guerra Fria já estava em andamento quase duas décadas antes de 1989. Na parte final, propõe-se a lógica da ação coletiva de Olson e o descompasso no desenvolvimento das regiões como instrumentais teóricos para compreender o caráter eminentemente instável da ordem internacional. A conclusão é que a complexa agenda internacional da realidade contemporânea não é muito diferente da que predominava na última década da Guerra Fria, mas a forma como as questões são percebidas e encaminhadas se modificou substancialmente.

\section{Abstract}

The core idea of the article is that the end of the Cold War in the last years of the eighties should not be viewed as a single fact, but as a part of a broad process of change. From this standpoint, it searches to prove, through the points of view expressed in several books and articles, that the process which led to the end of the Cold War was already in motion almost two decades before 1989. The second part of the article argues in favor of Olson's Logic of Collective Action and the existence of a gap between the development of world regions as theoretical frameworks to comprehend the naturally unstable feature of the international order. It concludes by stating that the complex contemporary international agenda is not quite different from the one which was predominant in the last decade of the Cold War, but the manner through which issues are realized and forwarded has substantially changed.

Palavras-chave: Guerra Fria. Globalização. Ação Coletiva. Desenvolvimento econômico.

Key-words: Cold War. Globalization. Collective action. Economic development. 